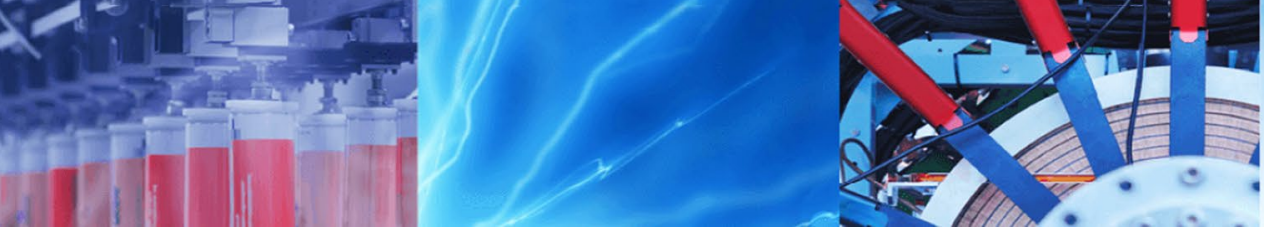

Research Article

\title{
Waste measurement for biogas generation to fulfill the electric energy demand of IUBAT: a case study
}

\author{
Md. Jahid Hasan ${ }^{1} \cdot$ Mahedi Hassan $^{1} \cdot$ Suman Chowdhury ${ }^{1}$ (I)
}

Received: 15 February 2020 / Accepted: 15 April 2020 / Published online: 24 April 2020

(c) Springer Nature Switzerland AG 2020

\begin{abstract}
For the depletion of fossil fuels, the world is facing an energy crisis. Therefore, a major concern for stakeholders around the world is the need to search for renewable alternative energy. Biogas is a type of bio-fuel that is naturally produced from the decomposition of organic waste. The main objective of this study is to design a biogas generator for utilization of cow dung, kitchen waste, rice waste, paper waste, tissue waste to generate biogas. This produced biogas can be used for generation of electricity for fulfilling the electricity demand of IUBAT-a private organization. Biogas plant is a new source of energy and is suitable for the future needs. This paper reflects the modeling, different types of wastes' $\mathrm{pH}$ measurement and finds out the best waste materials of biogas production digestion process from organic waste and high moisture food processing waste. In Bangladesh, the waste amount is increasing day by day. It is harmful for both our environment and life. So this waste can be a good potential, if it can be used for some valuable purposes. From this view, it can be said that working on Biogas is very important issue for understanding the potentiality of waste.
\end{abstract}

Keywords Biogas $\cdot \mathrm{pH}$ value $\cdot$ Load $\cdot$ IUBAT

\section{Introduction}

Biomass is the most promising among the renewable energy sources. Biomass refers to different forms of organic matter including crop residues, product-based agro-industrial, urban and municipal waste, animal dung [1]. A detailed study of world energy demands shows that firewood, charcoal, and crop residues make up more than $75 \%$ of the total energy consumed. It means the loss of the forest cover at a faster rate than attempts to raise trees. All of this study implies the loss of the forest cover at a faster rate than attempts to raise trees. Not only the cost involved, but also the very unpredictable weather patterns largely attributed to global warming, electrical power etc. [2,3]. Anaerobic digestion was theoretically seen as a desirable tool for stabilizing waste before landfills as a pretreatment to minimize substantial contamination in the atmosphere $[4,5]$. And to power a generator that generates electricity, it can be used to fuel internal combustion engines [6]. Biogas typically contains around 55-65\% of methane, $30-35 \%$ of carbon dioxide and hydrogen, nitrogen and other impurities [7]. The first step includes a group of anaerobic bacteria that produces organic acids as a by-product of the initial organic degradation, known as the acid formers. The second step includes a group of bacteria that breaks down the organic acids and produces methane as a by-product of organic acid degradation [8]. Anaerobic digestion was theoretically seen as a desirable tool for stabilizing waste before landfills as a pre-treatment to minimize significant environmental pollution $[9,10]$. Anaerobic digestion technology, as described above, is ideal for use in the production of biogas. Biogas generated

Suman Chowdhury, suman@iubat.edu; Md. Jahid Hasan, jahidhasanjoyueee@gmail.com; Mahedi Hassan, mehedihasan264@gmail. com | ${ }^{1}$ Department of Electrical and Electronic Engineering, International University of Business Agriculture and Technology, Dhaka 1230, Bangladesh. 
by anaerobic digestion can be used to power internal combustion engines to operate an electric generator [6]. The requirement to collect landfill gas has the effect of reducing the cost of landfill gas conversion to electricity [11]. The processing of biogas by anaerobic digestion (AD) is an environmentally friendly method that utilizes the growing quantities of organic waste generated worldwide [12]. With a strong agro-sector in these countries, reducing fertilizer emissions and generating renewable energy are equally strong driving forces that promote the growth of biogas in other countries, such as Portugal, Greece, Ireland, and many of the modern East [13]. The rate of biogas production is up to organic content of waste as well as masses of parameters that defines the conditions of decomposition (such as age and constitution of waste, temperature, humidity, $\mathrm{pH}$-varies with depth of filling, population of microbes, quality and quantity of alimentary substances) [14-16]. Biogas is combusted as it is in the generator unit and produces electricity $[15,17]$. The biomass is converted into biogas (methane, carbon dioxide and traces of other contaminant gases) after the anaerobic digestion process is completed. Like liquid digester (a fertilizer rich in nutrients) [18].

\section{Research methodology}

This report practically collects various samples of waste (cow dung, rice waste, papers waste, tissue waste, vegetable waste) and measuring the $\mathrm{pH}$ value. Load calculation has been done for the IUBAT University to measure the total amount of loads utilized in this organization (Fig. 1).

\section{Waste condition in Bangladesh}

This paper focuses on the status of Bangladesh's solid waste generation system, waste management system and waste management problems. Every day, the country generates around 8000 tons of solid waste from the six major cities (Dhaka, Chittagong, Khulna, Rajshahi, Barisal and Sylhet), of which Dhaka alone contributes about $70 \%$. Efforts are underway to develop the waste collection, storage, recycling, incineration and land-filling system [19] (Fig. 2).

\subsection{Biogas generation}

Figure 3 shows the basic operation of biogas generation process. An inlet is used for feeding the waste for digestion process and an out is used for taking out the digested waste after a fixed time interval. The produced gas is bypasses through a block where moisture is absorbed

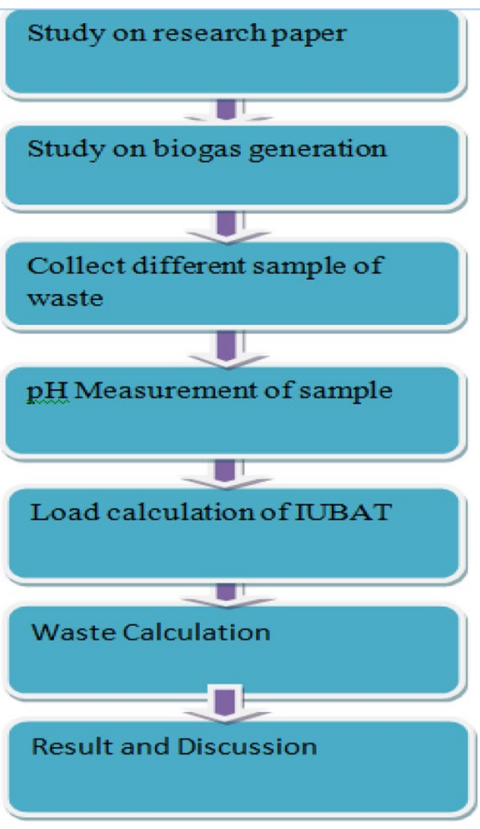

Fig. 1 Flow chart of methodology
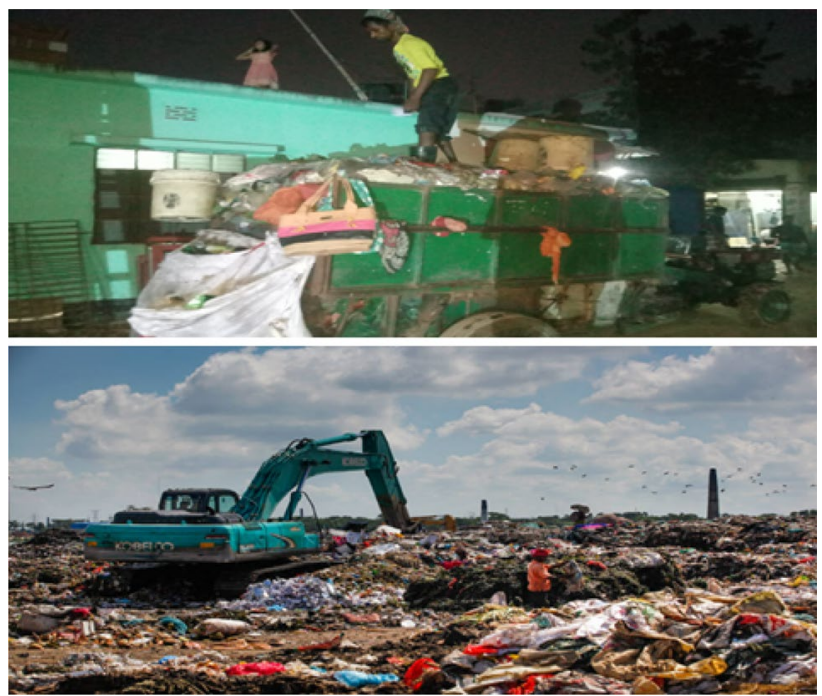

Fig. 2 Waste condition in Bangladesh

which may increase the potentiality of the biogas. After that this gas can be processed for power generation.

\section{$4 \mathrm{pH}$ Measurement and calculation}

Low $\mathrm{pH}$ prevents growth and gas production of methaneorganic bacteria and is often the result of overloading. Efficient digestion takes place at a $\mathrm{pH}$ similar to equilibrium, between 6.0 and 8.0. A slightly alkaline state is an 


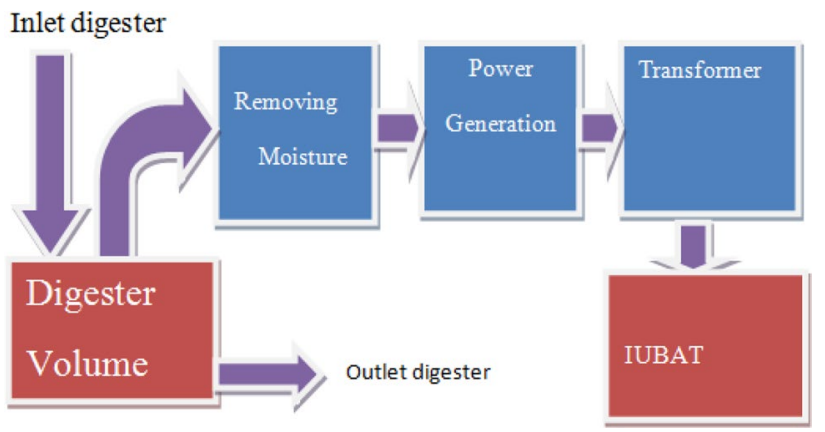

Fig. 3 Proposed block diagram of biogas generation
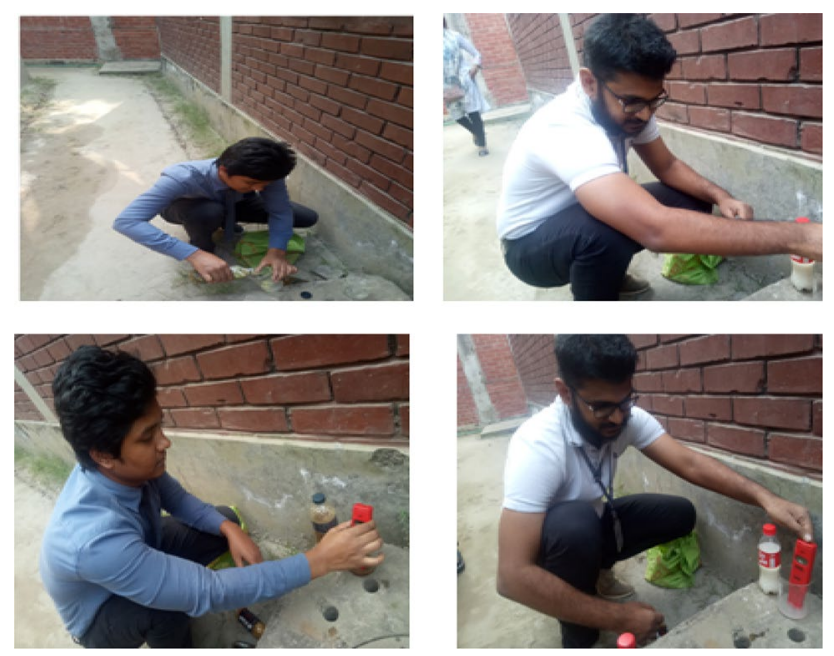

Fig. $4 \mathrm{pH}$ measurement experiment

indication of not being too drastic in $\mathrm{pH}$ fluctuations. Upon dilution or by adding acid, low pH can be relieved [18]. A low $\mathrm{pH}$ in the digester decreases the activity of especially bacteria that are involved in the digestion process [16] (Fig. 4).

Practical experiment has been done for the measurement of $\mathrm{pH}$ value of cowdung, vegetable waste, tissue paper, News papers and rice waste for one week.

Figure 5 shows the measurement of $\mathrm{pH}$ value of rice waste. In that case, the $\mathrm{pH}$ value gives lower value. That means in rice waste acidity is high.

The Table 1 is about the rice waste experimental and cumulative $\mathrm{pH}$ value with respect to retention time. This table is showing the $\mathrm{pH}$ value of rice waste for a week. If the amount of waste is increased the electricity of production also will be increased.

Figure 6 shows the measurement of $\mathrm{pH}$ value of tissue waste. In tissue waste firstly $\mathrm{pH}$ value has around the 7 . After some days its $\mathrm{pH}$ value decreased. After 7 or 10 days it reached to around $\mathrm{pH}$ value 6.
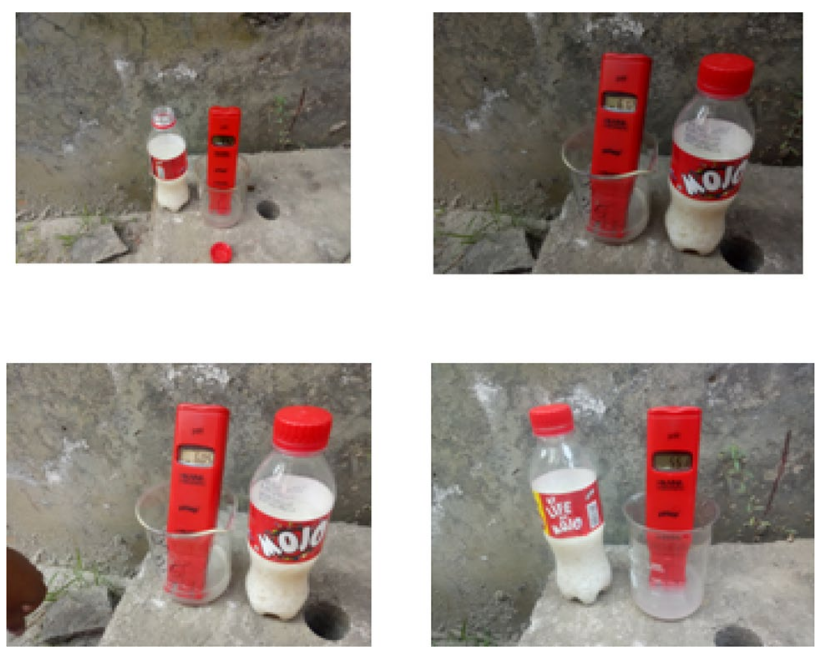

Fig. 5 Experiment set up for rice waste

Table $1 \mathrm{pH}$ measurement for rice waste

\begin{tabular}{|c|c|c|c|c|}
\hline \multirow[t]{2}{*}{ Date } & \multicolumn{4}{|l|}{ Time } \\
\hline & 9.00 a.m. & 12.00 p.m. & 3.00 p.m. & 5.00 p.m. \\
\hline 03-11-19 & 6.42 & 6.42 & 6.37 & 6.20 \\
\hline 04-11-19 & 6.12 & 6.05 & 5.88 & 5.70 \\
\hline 05-11-19 & 5.65 & 5.66 & 5.58 & 5.55 \\
\hline 06-11-19 & 5.51 & 5.48 & 5.40 & 5.41 \\
\hline 07-11-19 & 5.35 & 5.30 & 5.30 & 5.39 \\
\hline
\end{tabular}
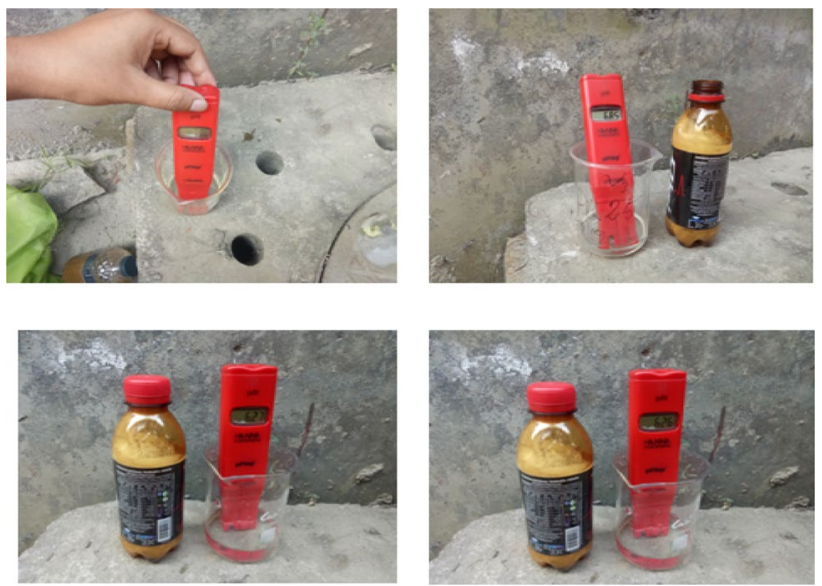

Fig. 6 Experiment set up for Tissue waste

Table 2 is about the rice waste experimental and cumulative $\mathrm{pH}$ value with respect to time. This table expressed the result of tissue paper waste with measured the $\mathrm{pH}$ value.

Figure 7 shows the measurement of $\mathrm{pH}$ value of paper waste. In paper waste firstly $\mathrm{pH}$ value has around the 7 . 
Table $2 \mathrm{pH}$ measurement of tissue waste

\begin{tabular}{lllll}
\hline Date & Time & & \\
\cline { 2 - 5 } & 9.00 a.m. & 12.00 p.m. & 3.00 p.m. & 5.00 p.m. \\
\hline $03-11-19$ & 7.11 & 7.17 & 7.22 & 7.25 \\
$04-11-19$ & 6.80 & 6.85 & 6.88 & 6.70 \\
$05-11-19$ & 6.80 & 6.89 & 6.75 & 6.85 \\
$06-11-19$ & 6.45 & 6.35 & 6.30 & 6.27 \\
$07-11-19$ & 6.26 & 6.21 & 6.15 & 6.11 \\
\hline
\end{tabular}
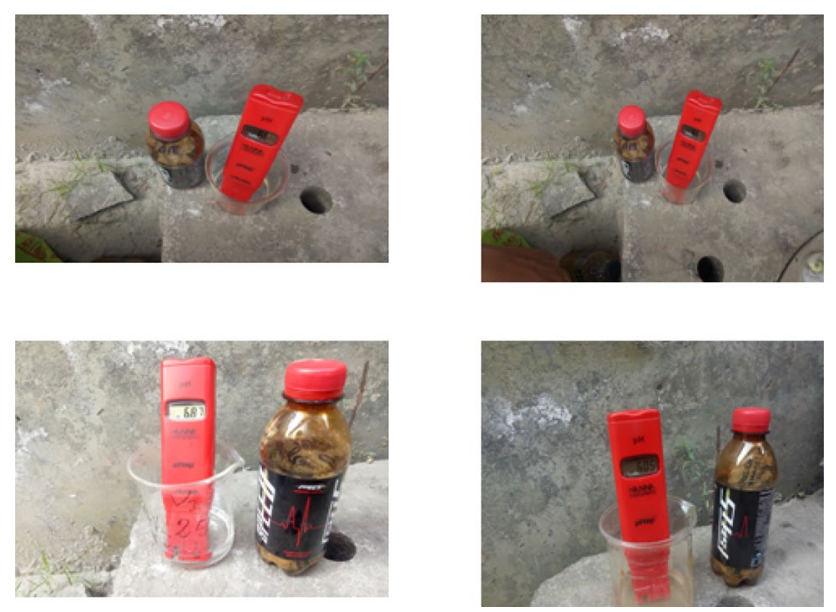

Fig. 7 Experiment set up for paper waste

Table $3 \mathrm{PH}$ measurement for paper waste

\begin{tabular}{lllll}
\hline Date & \multicolumn{3}{l}{ Time } \\
\cline { 2 - 5 } & 9.00 a.m. & 12.00 p.m. & 3.00 p.m. & 5.00 p.m. \\
\hline $03-11-19$ & 6.68 & 6.69 & 6.75 & 6.79 \\
$04-11-19$ & 6.87 & 6.82 & 6.66 & 6.66 \\
$05-11-19$ & 6.64 & 6.64 & 6.65 & 6.60 \\
$06-11-19$ & 6.58 & 6.50 & 6.23 & 6.25 \\
$07-11-19$ & 6.11 & 6.05 & 6.01 & 6.05 \\
\hline
\end{tabular}

After some days its $\mathrm{pH}$ value decreased. After 7 or 10 days it has reached to around $\mathrm{pH}$ value 5 .

The Table 3 is about the paper waste. The table is showing the cumulative $\mathrm{pH}$ value. In paper waste $\mathrm{pH}$ is not varied more. If the $\mathrm{pH}$ value is more (within 5 to 9), that means its batter for production of biogas.

Figure 8 shows taking the $\mathrm{pH}$ value of cow dung slurry. This slurry is made by the combination of water and cow dung. Its slurry ratio is $1: 1$. It is mixed until all the liquids are mixed in a bottle. In that case, the $\mathrm{pH}$ value decreased. That means in cow dung acidity is high. After a certain period it will be constant or increase the $\mathrm{pH}$ value (Fig. 9).
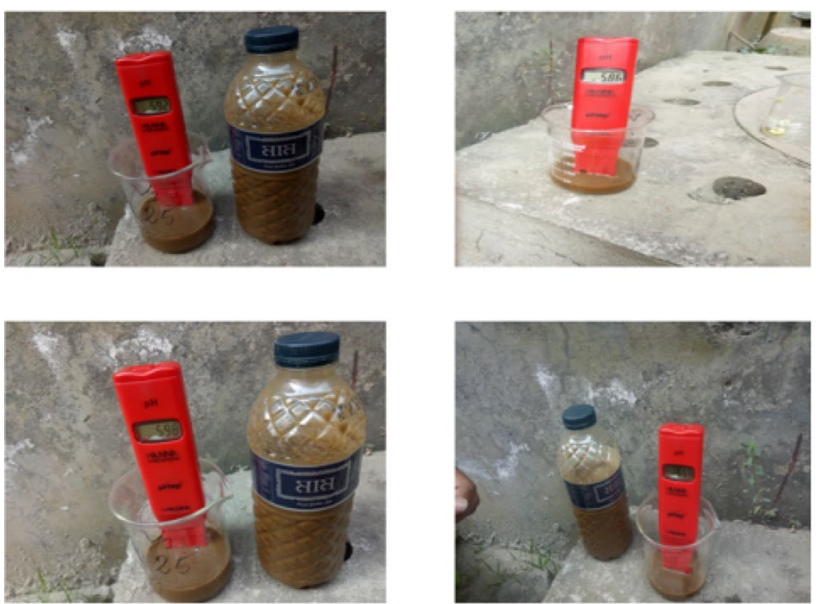

Fig. 8 Experiment set up for cow dung
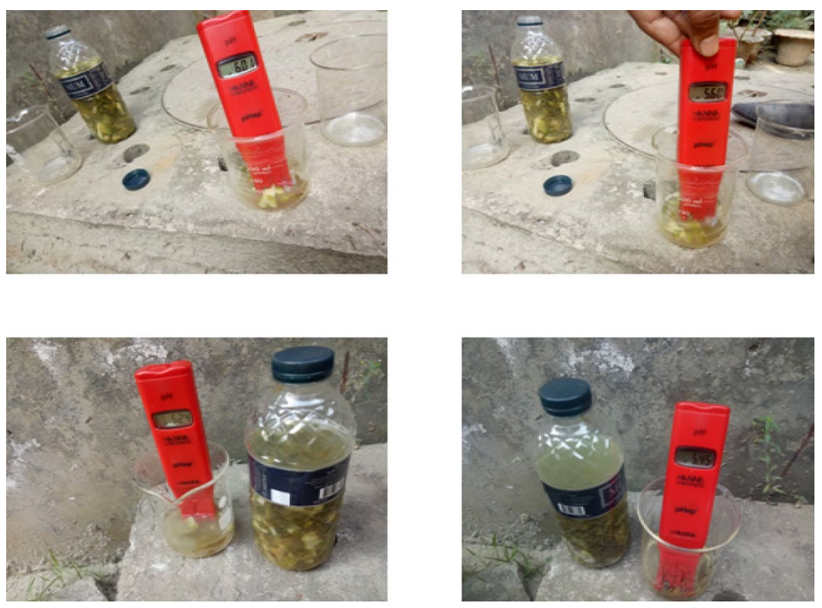

Fig. 9 Experiment set up for vegetable waste

Table $4 \mathrm{pH}$ measurement of cow dung

\begin{tabular}{|c|c|c|c|c|}
\hline \multirow[t]{2}{*}{ Date } & \multicolumn{4}{|l|}{ Time } \\
\hline & 9.00 a.m. & 12.00 p.m. & 3.00 p.m. & 5.00 p.m. \\
\hline 03-11-19 & 5.55 & 5.55 & 5.58 & 5.60 \\
\hline 04-11-19 & 5.68 & 5.66 & 5.66 & 5.68 \\
\hline 05-11-19 & 5.72 & 5.71 & 5.77 & 5.79 \\
\hline $06-11-19$ & 5.82 & 5.83 & 5.86 & 5.86 \\
\hline $07-11-19$ & 5.92 & 5.94 & 5.98 & 5.99 \\
\hline
\end{tabular}

Table 4 is showing the cumulative $\mathrm{pH}$ value of cow dung. In cow dung, the $\mathrm{pH}$ value is found between 5.55 and 5.99. That means in cow dung acidity is increased. After a certain period it will be constant or increase the $\mathrm{pH}$ value. 
Table 5 is showing the cumulative $\mathrm{pH}$ value of vegetable waste. In vegetable, we find the $\mathrm{pH}$ value is around 5.24 to 6.01 . That means in vegetable waste acidity is increased. After a certain period it will be constant or increase the $\mathrm{pH}$ value.

Table 6 is showing the load calculation for a day. Regarding this table daily total energy needs $6913.548 \mathrm{~kW} \mathrm{~h}$ for IUBAT. In university 988 ceiling fan rated $75 \mathrm{~W}$ each, 546 wall fan rated $50 \mathrm{~W}$ each, 2616 lights rated as $35 \mathrm{~W}$ each, 704 computers rated $65 \mathrm{~W}$ each, 68 projectors rated as $150 \mathrm{~W}$ each, $54 \mathrm{AC}$ rated as $1988 \mathrm{Watt}$ each. IUBAT total energy demand is $6,913,548 \mathrm{~W} \mathrm{~h}$.

Cow dung calculation:

Daily time duration $\mathrm{t}=9 \mathrm{~h}$

Total Power $p=768,172 \mathrm{~W}$

Total Energy $=p^{*} \mathrm{t}=768172 * 9=6913.548 \mathrm{kWh}$

$1 \mathrm{kWh}=3.6^{*} 10^{6} \mathrm{j}=6913.54^{*} 3.6^{*} 10^{6} \mathrm{j}$

So daily energy consumption $=2.488^{*} 10^{10} \mathrm{j}$ per day

Using cow dung production of biogas per $\mathrm{kg}$ of fresh dung $=0.09 \mathrm{~m}^{3}$

Calorific Value of the biogas produce $=20 \frac{\mathrm{Mj}}{\mathrm{m}^{3}}=20^{*} 10^{6} \frac{\mathrm{j}}{\mathrm{m}^{3}}$

Total amount of biogas required $=\frac{2.488 * 10^{10}}{20 * 10^{6}}=1244 \mathrm{~m}^{3}$

Total amount of cow dung required $=$ $\frac{1244 \mathrm{~m}^{3}}{0.09 \frac{\mathrm{m}^{3}}{\mathrm{~kg}}}=13822.22 \mathrm{~kg}$

Slurry

Cow dung slurry ratio $=1: 1$

Mass of slurry per day $=$ (mass of cow dung + mass of water $=13,822.22 \mathrm{~kg}+13,822.22 \mathrm{~kg}=27,644.44 \mathrm{~kg} /$ day

Density of the slurry, $\mathrm{D}=1000 \frac{\mathrm{kg}}{\mathrm{m}^{3}}$

Volume of the slurry $v=\frac{m}{D}=\frac{27644.44 \mathrm{~kg}}{1090 \frac{\mathrm{kg}}{\mathrm{m}^{3}}}=25.36 \mathrm{~m}^{3} /$ day

The retention time 30 days digester Volume $=$ Volume of the slurry ${ }^{*}$ Retention time $=\left(25.36 \mathrm{~m}^{3} /\right.$ day) $* 30$ day $=760.8 \mathrm{~m}^{3}$

Actual volume should be $10 \%$ more to probity, some space for proper digestion.

Actual digestion value $=760.8 * 10 \%+760.8=836.8 \mathrm{~m}^{3}$ Vegetable wastecalculation

Vegetable Waste Products:

Daily time duration $\mathrm{t}=9 \mathrm{~h}$

Table $5 \mathrm{PH}$ measurement for Kitchen waste

\begin{tabular}{|c|c|c|c|c|}
\hline \multirow[t]{2}{*}{ Date } & \multicolumn{4}{|l|}{ Time } \\
\hline & 9.00 a.m. & 12.00 p.m. & 3.00 p.m. & 5.00 p.m. \\
\hline 03-11-19 & 6.01 & 5.97 & 5.65 & 5.60 \\
\hline 04-11-19 & 5.45 & 5.45 & 5.47 & 5.33 \\
\hline 05-11-19 & 5.29 & 5.25 & 5.24 & 5.24 \\
\hline $06-11-19$ & 5.15 & 5.17 & 5.17 & 5.17 \\
\hline 07-11-19 & 5.10 & 5.14 & 5.09 & 5.02 \\
\hline
\end{tabular}

Table 6 Data table of IUBAT loads

\begin{tabular}{lccrr}
\hline $\begin{array}{l}\text { Types of } \\
\text { load }\end{array}$ & No of loads & $\begin{array}{l}\text { Rating } \\
\text { of loads } \\
(\mathrm{W})\end{array}$ & $\begin{array}{r}\text { Total power } \\
\text { consump- } \\
\text { tion, } P(\mathrm{~W})\end{array}$ & $\begin{array}{r}\text { Total energy, } \\
E=P^{*} t \\
(t=9 \mathrm{~h})\end{array}$ \\
\hline Ceiling fan & 988 & 75 & 74,100 & 666,900 \\
Wall fan & 546 & 50 & 27,300 & 245,700 \\
Light & 2616 & 35 & 91,560 & 824,040 \\
Computer & 704 & 65 & 457,660 & $4,118,940$ \\
Projector & 68 & 150 & 10,200 & 91,800 \\
AC (2 ton) & 54 & 1988 & 107,352 & 966,168 \\
Total energy & & & $768,172 \mathrm{~W}$ & $6,913,548 \mathrm{~W}$ \\
\hline
\end{tabular}

Total Power $\mathrm{P}=768,172 \mathrm{~W}$

Total Energy $=\mathrm{p}^{*} \mathrm{t}=768172^{*} 9=6913.54 \mathrm{~kW} \mathrm{~h}$

$1 \mathrm{kWh}=3.6^{*} 10^{6} \mathrm{j}=6913.54^{*} 3.6^{*} 10^{6} \mathrm{j}$

So daily energy consumption $=2.488^{*} 10^{10} \mathrm{j}$ per day

Using Vegetable waste production of biogas per day $\mathrm{kg}=0.05 \mathrm{~m}^{3}$

Calorific Value of the biogas produce $=20 \frac{\mathrm{Mj}}{\mathrm{m}^{3}}=20^{*} 10^{6} \frac{\mathrm{j}}{\mathrm{m}^{3}}$

Total amount of biogas required $=\frac{2.488 * 10^{10}}{20 * 10^{6}}=1244 \mathrm{~m}^{3}$

Total amount of vegetable waste bio gas required $=\frac{1033 \mathrm{~m}^{3}}{0.05 \frac{\mathrm{m}^{3}}{\mathrm{~kg}}}=24,880 \mathrm{~kg} /$ per day

Slurry

Vegetable waste slurry ratio $=1: 1$

Mass of slurry per day $=$ (mass of vegetable wastes + mass of water) $=24,880+24880=49,760 \mathrm{~kg}$

Density of the slurry $D=1000 \frac{\mathrm{kg}}{\mathrm{m}^{3}}$

Volume of the slurry $v=\frac{m}{D}=\frac{49760 \mathrm{~kg}}{1090 \frac{\mathrm{kg}}{\mathrm{m}^{3}}}=35.65 \mathrm{~m}^{3}$

The retention time 30 days digester Volume $=$ Volume of the slurry ${ }^{*}$ Retention time $=35.65^{*} 30=1069.5 \mathrm{~m}^{3}$

Actual volume should be $10 \%$ more to probity, some space for proper digestion (Table 7).

Actual digestion value $=1137^{*} 10 \%+1137=1176.45 \mathrm{~m}^{3}$

Table 7 Digester volume table

\begin{tabular}{lll}
\hline Name & Cow dung & Vegetable waste \\
\hline $\begin{array}{l}\text { Total amount of biogas } \\
\text { required }\end{array}$ & $1244 \mathrm{~m}^{3}$ & $1244 \mathrm{~m}^{3}$ \\
Total mass & $13,822.22 \mathrm{~kg} /$ day & $24,880 \mathrm{~kg} /$ day \\
Volume of slurry & $25.36 \mathrm{~m}^{3}$ & $35.65 \mathrm{~m}^{3}$ \\
Digester volume & $760.8 \mathrm{~m}^{3}$ & $1069.5 \mathrm{~m}^{3}$ \\
Actual digester volume & $836.8 \mathrm{~m}^{3}$ & $1176.45 \mathrm{~m}^{3}$ \\
\hline
\end{tabular}




\section{Conclusion}

$\mathrm{pH}$ is a very important parameter in the anaerobic digestion process. It has been observed that the variation of $\mathrm{pH}$ value is directly related with the anaerobic digestion process. The experiment has been done for one week. $\mathrm{pH}$ measurement has been done for cow dung, kitchen waste, rice waste, tissue waste and paper waste. For Kitchen waste $\mathrm{pH}$ is maximum 5 which is less than cow dung. The $\mathrm{pH}$ value is highest for cow dung than the value of different samples like vegetable waste, rice waste, tissue waste, paper waste. From the load calculation, it has been perceived that how much biogas is needed to produce the electricity for IUBAT. Daily total energy consumption is $6913.54 \mathrm{~kW}$ h of IUBAT.

\section{Compliance with ethical standards}

Conflict of interest The authors declare that there is no conflict of interest.

\section{References}

1. Ogur EO (2013) Design of a biogas generator. J Eng Res Appl 3(6):630-635

2. Reith JH, Wijffels RH, Barten H (2003) Bio-methane and biohydrogen: status and perspectives of biological methane and hydrogen production. Dutch Biological Hydrogen Foundation - NOVEM, The Hague (ISSN: 9090171657)

3. Drapcho CM, Nhuan NP, Walker TH (2008) Biofuels engineering process technology. McGraw Hill, New York. ISBN 978-007-148-749-8

4. Juanka J, Kuruparan P, Visvanathan C. Optimizing combined anaerobic digestion process of organic fraction of municipal solid waste (MSW)

5. Soupios PM, Vallianatos FC, Papadopoulos ITh, Makris JP, Marinakis D (2005) Surface-geophysical investigation of a landfill in Chania, Crete. In: GEOENV2005, Proceedings of the international workshop in geoenvironment and geotechnics, pp 149-156

6. Rozdilsky JL (1997) Farm-based anaerobic digestion in Michigan history, current status and future outlook. Report of Michigan Biomass Energy Program
7. Tsapekos P, Kougias PG, Treu L, Campanaro S, Angelidaki I (2017) Process performance and comparative metagenomic analysis during co-digestion of manure and lignocellulosic biomass for biogas production. Appl Energy. https://doi.org/10.1016/j. apenergy.2016.10.081

8. Rutledge B (2005) California biogas industry assessment. White paper

9. Juanka J, Kuruparan P, Visvanathan C (2007) Optimization of anaerobic digestion of municipal solid waste in combined process and sequential staging. Waste Manag Res. https://doi. org/10.1177/0734242x07072085

10. Soupios PM, Vallianatos FC, Papadopoulos ITh, Makris JP, Marinakis D (2005) Surface-geophysical investigation of a landfill in Chania, Crete. In: GEOENV 2005, Proceedings of the international workshop in geoenvironment and geotechnics, pp 149-156

11. Kersteller JD. Biomass briefing paper. Washington State University

12. Li Y, Zhang R, Liu G, Chen C, He Y, Liu X (2013) Comparison of methane production potential, biodegradability, and kinetics of different organic substrates. Bioresour Technol. https://doi. org/10.1016/j.biortech.2013.09.063

13. Kougias PG, Boe K, Tsapekos P, Angelidaki I (2014) Foam suppression in overloaded manure-based biogas reactors using antifoaming agents. Bioresour Technol 153(2):198-205

14. Reinhart DR (1994) Beneficial use of landfill gas. Final Report, Florida Center for Solidand Hazardous Waste Management

15. Kumar S, Mondal AN, Gaikwad SA, Devotta S, Singh RN (2004) Qualitativeassessment of methane emission inventory from municipal solid waste disposal sites: acase study. Atmos Environ 38:4921-4929

16. Jayaraj S, Deepanraj B, Sivasubramanian V (2014) Study on the effect of $\mathrm{pH}$ on biogas production from food waste by anaerobic digestion. https://www.researchgate.net/publication/26454 5493

17. Implementation Guide for Landfill Gas Recovery Reports in the Northeast, Final Report, Policy Research Center, Washington (1994)

18. Raja IA, Wazir S (2017) Biogas production: the fundamental processes. Univ J Eng Sci. https://doi.org/10.13189/ujes.2017.05020 2

19. Abedin MdA, Jahiruddin M (2015) Waste generation and management in Bangladesh: an overview. Asian J Med Biol Res 1(1):114-120

Publisher's Note Springer Nature remains neutral with regard to jurisdictional claims in published maps and institutional affiliations. 